\title{
The Effect of Reciprocal Teaching Model on Students' Self-Regulated Mathematics Learning in SMPN 2 Patikraja Banyumas Regency
}

\author{
Maria Ulpah*, Zaenurrohman, Muh. Naffi Sahly \\ Mathematics Education Department, IAIN Purwokerto, \\ Jl. A. Yani No 42 A Purwokerto 53126, Indonesia. Tel. +62-281-635624, Fax. +62-281-636553. \\ Email*: ulfah1511@yahoo.co.id
}

\begin{abstract}
In mathematics learning, not only cognitive abilities, but affective abilities also need to be improved, especially the ability to learn independently or self-regulated learning. Self-regulated learning is very important because the attitude of independence aims to be able to direct students towards positive behavior that can support success in the learning process. Self-regulated learning makes students trained and manages every action, so students have discipline in the learning process. Students who have good self-regulated learning can complete the task and are able to overcome a learning problem. The learning model that is thought to improve self-regulated learning is reciprocal teaching. This model requires students to study independently with strategies to summarize, make questions, explain, and predict answers. This research uses quantitative approach with a quasi-experiment, conducted in $8^{\text {th }}$ grade of SMPN 2 Patikraja, Banyumas Regency. The instrument used to measure self-regulated learning is a questionnaire consisting of 24 valid questions. The results of this study indicate that there is an effect of the reciprocal teaching model on students' self-regulated mathematics learning. This can be seen from the average score of $n$-gain 0.353 in the medium category.
\end{abstract}

Keywords: Mathematics, learning, reciprocal teaching, self-regulated

\section{INTRODUCTION}

In addition to cognitive abilities, affective abilities in learning mathematics also need attention (Ulpah 2019). Especially on the ability to learn independently or selfregulated learning. Self-regulated learning is very important, because the attitude of autonomous aims to be able to direct yourself towards positive behavior that can support success in the learning process. With autonomous makes students trained and have the habit of doing good actions and can manage every action so that students have discipline in the learning process. In learning, autonomous is needed so that students have the responsibility in managing and disciplining themselves, but also in developing learning abilities of their own volition. Each student must have self-regulated learning and be required to be independent in order to be able to complete tasks and be able to overcome a problem in terms of study.

Schunk and Zimmerman define self-regulated learning as a learning process that occurs due to the influence of one's own thoughts, feelings, strategies, and behaviors which are oriented to the achievement of goals (Hendriana). According to Schunk and Zimmerman there are three main phases in the cycle of self-regulated learning, namely: designing learning, monitoring learning progress while implementing the design, and evaluating learning outcomes in full. Next, Schunk and Zimmerman detailed the activities that took place in each phase of self-regulated learning as follows: a) designing learning; b) monitor learning activities; c) evaluate and reflect. Similar to Schunk and Zimmerman, Butler argues that self-regulated learning is a cycle of recursive cognitive activities that includes activities: analyzing tasks, choose, adopt, or find a strategic approach to achieving the objectives of the task; and monitor the results of the strategies that have been implemented.

Today, students' self-regulated learning abilities are still low, as seen from students' lack of readiness to accept new material provided by teachers. This also happened at SMP Negeri 2 Patikraja, Banyumas Regency, where students' interest in autonomous learning was still low, and students were still reluctant to study subject matter at home, which caused students to not be ready to accept the lessons given by the teacher. Self-regulated learning of eighth grade students of SMP Negeri 2 Patikraja which is still low is caused by two factors, namely internal factors (within students) and external factors (outside students), internal factors that can affect students' self-regulated learning are students not yet learning material will be delivered by the teacher, reviewing what he has learned at home. While the external factors that influence are the teacher giving the material using only the lecture learning model, which positions students only as objects, and students are accustomed to learning concepts, and formulas by memorizing without understanding concepts in depth.

This is in accordance with the factors that influence student learning according to Slameto (2015) namely internal factors and external factors. Internal factors according to Slameto are divided into three factors namely physical factors (health and disability), psychological factors (intelligence, attention, interest, 
talent, motives, maturity, and readiness), and fatigue. Meanwhile, external factors are family factors (the way parents educate, relationships between family members, household atmosphere, and family economic conditions), school factors (teaching methods, curriculum, studentstudent relations, school discipline, learning tools, school time, standard lessons above the size, condition of the building, learning methods, and homework assignments, as well as community factors (student activities in the community, mass media, associate friends, and community life forms).

Self-regulated learning has a very important role. Therefore, teachers must be able to provide motivation and provide varied learning models to improve selfregulated learning. It is suspected that the reciprocal teaching learning model can improve this ability. According to Nurhasanah (Muslimin, et al 2017), the characteristics of the reciprocal teaching learning model are students becoming "teachers" by applying 4 strategies, namely: questioning, predicting, clarifying, and summarizing. In the asking stage, students ask questions to the "teacher" about the description of the material contained in the worksheet. The next stage is the prediction stage, at these stage students make predictions about the material being studied. Then in the explaining stage, students explain the predictions that students have made. In the summarizing stage, students are asked to conclude the subject matter. After making conclusions, the "teacher" asks representatives from several groups to present their conclusions in front of the class. In the end the teacher, "teacher" and student together summarize the results that have been presented and discussed together.

A research conducted by Trisaputri (2017) concluded that reciprocal teaching model influences students' selfregulated learning. Other studies have been carried out to develop students' self-regulated learning (Kim \& Noor 2019; Putri 2017). Reciprocal teaching which requires students to study independently with strategies to summarize, make questions, explain, and predict answers is thought to improve understanding of the concept of space building and self-regulated learning of eighth grade students of SMP Negeri 2 Patikraja. Therefore, the researcher is interested to know whether there is an influence of the reciprocal teaching learning model on self-regulated learning of Grade VIII students of SMP Negeri 2 Patikraja, Banyumas Regency.

\section{MATERIALS AND METHODS}

\section{Study area}

This type of research is quasi experiment with nonequivalent control group design which in this design there are two groups, namely the experimental group and the control group. This was conducted in $8^{\text {th }}$ grade students of SMP Negeri 2 Patikraja, Banyumas Regency. The population is 64 students which are divided into two classes, namely class A as experimental group and class $\mathrm{B}$ as control group.

\section{Procedures}

This research was conducted five times, where the first meeting was the giving of a pre-test to find out the initial conditions of students' self-regulated learning in the control and experiment class. The next three meetings were giving treatment in the experimental class using the reciprocal teaching model, while the control class used the learning method as usual, namely expository and drill. The last meeting was giving a post-test to find out the final condition about students' self-regulated learning.

Instrument that is used to measure self-regulated learning in this research was questionnaire. The questionnaire consists of 24 valid questions which were given before and after learning process. The indicators of self-regulated learning in this research are (Sumarmo: 2004):

1. Learning initiative.

2. Diagnose learning needs.

3. Set learning targets and goals.

4. Monitor, regulate, and control the progress of learning.

5. See difficulties as challenges.

6. Utilize and find relevant sources.

7. Choosing and implementing learning strategies.

8. Evaluating learning processes and results.

9. Has a self-concept.

\section{Data analysis}

The data was analyzed by using N-Gain. N-Gain provides information about increasing self-regulated learning. The N-Gain Score is determined using the following formula (Eka, 2016):

$$
N-\text { Gain }=\frac{S_{\text {Post }}-S_{\text {Pre }}}{S_{\text {maks }}-S_{\text {Pre }}}
$$

$S_{\text {Post }}:$ post test score

$S_{\text {Pre }}:$ pretest score

$S_{\max }$ : maximum score

The N-gain criteria are determined as follows:

Table 1. $N$-Gain Criteria.

\begin{tabular}{ll}
\hline Interval score & Category \\
\hline$N$-Gain $>0,7$ & High \\
$0,3 \leq N$-Gain $\leq 0,7$ & Middle \\
$N$-Gain $<0,3$ & Low \\
\hline
\end{tabular}




\section{RESULTS AND DISCUSSION}

\section{Result}

Learning in the experimental class used a reciprocal teaching learning model. The steps are as follows:

1. Learning begins with the teacher delivering the benefits and learning objectives as well as the learning steps that will be implemented.

2. The teacher divides students into groups of 4 to 5 students with heterogeneous characteristics.

3. The teacher gives a worksheet to each group.

4. The teacher chooses one student in each group to act as the teacher in the group.

5. The teacher asks students to read and understand the worksheets that have been given.

6. Clarifying

a. The teacher asks students to clarify the material contained in the worksheet by reading, understanding and discussing the material with a group of friends led by students who act as teachers (the teacher guides students in group discussions) in order to find the volume formula for cubes, beams, prisms, and pyramid.

b. The teacher provides opportunities for students to ask questions that are considered difficult.

c. The teacher asks students to discuss working on the exercises on the worksheet in groups.

7. Predicting

The teacher asks students to predict the relationship between the concepts they have just learned and the concepts they have learned.

8. Questioning Generating

The teacher asks students to make questions about the material discussed and then immediately answered by discussing with the group.

9. Summarizing

The teacher asks students to make a summary of the material and questions they have learned.

10. The teacher asks students who act as teachers in their groups to present the results of group discussions in front of the class, while the other groups pay attention, respond or ask questions.

11. The teacher asks students which material is still considered difficult

12. The teacher concludes learning material.

Students' self-regulated learning data is obtained from filling out a questionnaire conducted by each student. The self-regulated learning questionnaire was given before and after treatment to determine the effect of the reciprocal teaching learning model on students' self-regulated learning. The data of students' selfregulated learning of experimental class students can be seen in the following table:
Table 2. Data of Self-Regulated Learning of Experimental Group.

\begin{tabular}{lll}
\hline \multirow{2}{*}{ Description } & \multicolumn{2}{l}{ Experimental group } \\
\cline { 2 - 3 } & Pretest & Post test \\
\hline Number of students & 32 & 32 \\
Average & 64.72 & 73.81 \\
Maximum score & 75 & 84 \\
Minimum score & 42 & 57 \\
\hline
\end{tabular}

Based on Table 2, it can be concluded that there was an increase in self-regulated learning of experimental class students which initially averaged 64.72, after being given a reciprocal teaching learning model the average self-regulated learning of students became 73.81. While the results of the description of self-regulated learning data of control class students can be seen in the following table:

Table 3. Data of Self -Regulated Learning of Control Group.

\begin{tabular}{lll}
\hline \multirow{2}{*}{ Description } & Control group \\
\cline { 2 - 3 } & Pretest & Post test \\
\hline Number of students & 32 & 32 \\
Average & 64.78 & 69.34 \\
Maximum score & 81 & 87 \\
Minimum score & 53 & 56 \\
\hline
\end{tabular}

Based on Table 3, it can be concluded that there was an increase in self-regulated learning of control class students, which was originally averaging 64.78, after being given a reciprocal teaching learning model, the average self-regulated learning of students became 69.34.

Furthermore, to see an increase in self-regulated learning, an analysis is performed using N-Gain. N-Gain of experimental group is determined as follows:

Table 4. N-Gain of Self-Regulated Learning of Experimental Group.

\begin{tabular}{llll}
\hline $\begin{array}{l}\text { Number of } \\
\text { students }\end{array}$ & $\begin{array}{l}\text { Maximum } \\
\text { N-Gain }\end{array}$ & $\begin{array}{l}\text { Minimum } \\
\text { N-gain }\end{array}$ & Average \\
\hline 32 & 0.5 & 0.2 & 0.353 \\
\hline
\end{tabular}

Based on Table 4, it can be seen that the average of Self-regulated learning N-Gain of the experimental class is 0.353 , which is included in the middle category. Then, the control class N-Gain is determined as follows:

Table 5. N-Gain of Self-Regulated Learning of Control Group.

\begin{tabular}{llll}
\hline $\begin{array}{l}\text { Number of } \\
\text { students }\end{array}$ & $\begin{array}{l}\text { Maximum } \\
\text { N-Gain }\end{array}$ & $\begin{array}{l}\text { Minimum } \\
\text { N-Gain }\end{array}$ & Average \\
\hline 32 & 0.7 & 0.1 & 0.163 \\
\hline
\end{tabular}

Based on Table 5, it can be seen that the average of Self-regulated learning N-Gain of the control class is 0.163 , which is included in the low category.

Reciprocal teaching learning models that can motivate students to learn independently lead to 
differences in the average scores of students' selfregulated learning $\mathrm{N}-\mathrm{Gain}$ in the experimental class and the control class. The difference in the N-Gain average of the experimental class and the control class shows that there is an effect of the reciprocal teaching learning model on self-regulated learning of Grade VIII students of SMP Negeri 2 Patikraja, Banyumas Regency, with a middle category. It also indicates that the reciprocal teaching learning model can further enhance students' self-regulated learning abilities compared to learning using conventional learning models.

\section{Discussion}

The results of the initial analysis of the self-regulated learning questionnaire data in the experimental class and the control class show that both are in the middle category. The final results of self-regulated learning questionnaire data for the experimental class and the control class showed improvement after participating in the learning.

Based on the data that has been described previously, it appears that the final results of the student selfregulated learning questionnaire data taught using the reciprocal teaching learning model have an average score of 73.81. whereas if seen from the increase in students' self-regulated learning using $\mathrm{n}$-gain, this experimental class is in the middle category with an average score of 0.353 .

Descriptively, it is known that the final results of the self-regulated learning questionnaire control class students have an average of 69.34. From the increase in self-regulated learning of control class students using ngain, the average is 0.163 , the score shows an increase in self-regulated learning of students with a low increase category.

Reciprocal teaching learning models that can motivate students to learn independently lead to differences in the average score of $\mathrm{n}$-gain self-regulated learning students in the experimental class and the control class. The difference in the average n-gain score of the experimental class and the control class, shows that there is an effect of the reciprocal teaching model on students' self-regulated learning with a middle influence category. It also indicates that the reciprocal teaching model can further enhance students' self-regulated learning.

\section{CONCLUSIONS}

Self-regulated learning is very important because the attitude of independence aims to be able to direct students towards positive behavior that can support success in the learning process. Self-regulated learning makes students trained and manages every action, so students have discipline in the learning process. Students who have good self-regulated learning can complete the task and are able to overcome a learning problem. The learning model that is thought to improve self-regulated learning is reciprocal teaching. This model requires students to study independently with strategies to summarize, make questions, explain, and predict answers.

\section{REFERENCES}

Ali, Mohammad. 1992. Strategi Penelitian Pendidikan. Angkasa, Bandung.

Arikunto, Suharsimi. 2005. Dasar-dasar Evaluasi Pendidikan. Bumi Aksara, Jakarta.

Djamarah, Syaiful Bahri. 2015. Psikologi Belajar. Rineka Cipta, Jakarta.

Eka Prisiani, Devi, dkk. 2016. Pengaruh Pendekatan Reciprocal Teaching Terhadap Kemampuan Pemahaman Konsep Pada Pembelajaran Matematika Di Kelas X SMA Muhammadiyah 2 Palembang. Jurnal Pendidikan Matematika JPM RAFA Vol.2, No.2.

Gurria, Angel. 2016. PISA 2015: PISA Results in Focus. OECD 2016.

Hendriana, Heris, dkk. 2017. Hards Skills dan Soft Skills Matematika Siswa. PT Refika Aditama, Bandung.

Kim, S. S. and Nor, M. M. 2019. The Effect of Self-Regulated Learning Strategies on Preschool Childrens' Self-Efficacy and Performance in Early Writing. International Journal of Education Universitas Pendidikan Indonesia 11: 2.

Muslimin, Indaryanti, Susanti, E. 2017. Pembelajaran Matematika dengan Model Reciprocal Teaching untuk Melatih Kecakapan Akademik Siswa Kelas VIII SMP. Jurnal Pendidikan Matematika 11: 1

National Council of Teachers of Mathematics. 2000. Principles and Standars for School Mathematics. Reston, VA: NCTM.

Overview TIMSS and PIRLS 2011 Achievement posted in TIMSS and PIRLS, 2011 (http://timssandpirls.bc.edu).

Putri, M. R. E. 2017. Hubungan antara Self-Regulated Learning dan Stres Akademik pada Mahasiswa. [Thesis]. Sanata Dharma University, Yogyakarta. [Indonesian]

Shoimin, Aris. 2017. 68 Model Pembelajaran Inovatif dalam Kurikulum 2013. Yogyakarta: Ar-Ruzz Media.

Slameto. 2015. Belajar dan Faktor-faktor yang Memperngaruhinya. Rineka Cipta, Jakarta.

Sugiyono. 2015.Metode Penelitian Pendidikan (Pendekatan Kuantitatif, Kualitatif, dan R\&D). Alfabeta, Bandung.

Sumarmo, U. 2004. Kemandirian Belajar Apa, Mengapa, dan Bagaimana Dikembangkan pada Peserta Didik. Proceeding of Mathematics Education Conference of Universitas Negeri Yogyakarta, Yogyakarta.

Trianto. 2007. Model-model Pembelajaran Inovatif Berorientasi Konstruktivistik. Prestasi Pustaka Publisher, Jakarta.

Trisaputri, Fatiya. 2017. Pengaruh Pembelajaran Reciprocal Teaching Terhadap Kemampuan Komunikasi dan Self Regulated Learning Matematis Siswa SMA. [Thesis]. Pasundan University, Bandung. [Indonesian]

Ulpah, M. 2019. Self-Efficacy dalam Pembelajaran Matematika Siswa Madrasah Aliyah. Insania: 167-176.

Zimmerman, Barry J. 1989. A Social Cognitive View of SelfRegulated Academic Learning, Journal of Education Psychology Vol. 81, No. 3. 